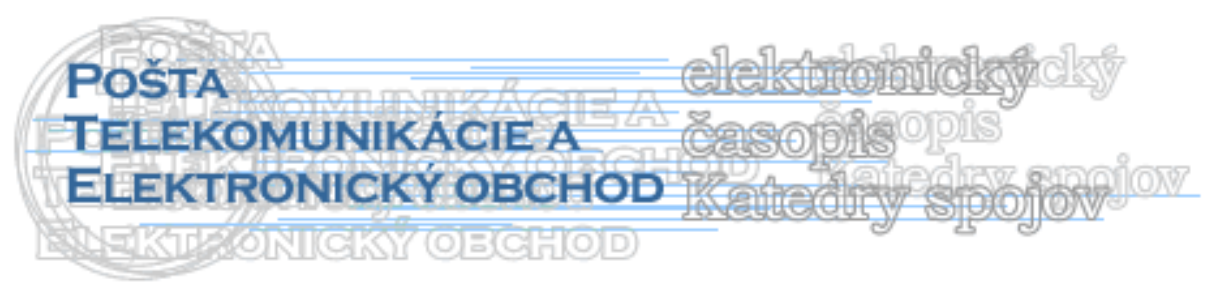

\title{
DYNAMICKÁ STRATEGICKÁ ROZVAHA AKO JEDEN ZO SMEROV STRATEGICKÉHO MYSLENIA
}

\author{
Jana Tulisová*
}

\section{Úvod}

Metodologická výstavba strategického myslenia stagnuje už dlhšie obdobie. PhDr. Ivan Fišer, člen fakulty CMC Graduate School of Business, navrhuje novú metódu strategického myslenia, ktorú úspešne overil v praxi.

V medzinárodne uznávaných publikáciách i v praxi je dlhodobo zastávaný názor používania SWOT analýzy, kombinujúcej silné a slabé stránky podniku s jeho príležitost'ami a hrozbami. Jej používatelia sa stretávajú s pochybnost'ami, či stratégia zkonštruovaná na základe SWOT analýzy zodpovedá dnešnej dynamickej skutočnosti. Túto skutočnost' by mala zohladnit' nová metóda strategického myslenia, tzv. Dynamická strategická rozvaha (DSR), ktorá bola úspešne overená pri výuke i pri aplikáciách na podnikové situácie. Prax poukazuje na to, že metóda je pozitívne prijatá ako logický a praktický postup a že jednotlivci i podniky sú po úvodnom školení schopní metódu použit' i bez priebežného , a preto nákladného poradenského vedenia. Môžu tak samostatne dospiet' k závažným strategickým doporučeniam a rozhodnutiam.

\section{Podstata DSR}

Podstatu Dynamickej strategickej rozvahy (DSR) najlepšie vyjadruje nasledujúci obrázok 1. Obrázok vychádza $\mathrm{z}$ jednoduchého a logického predpokladu, že základom strategického rozhodovania sú dielčie scénare vývoja podstatných faktorov budúceho oboru podnikania (kroky 1-6) . Tie je nutné vzájomne prepojit' a v rámci daného oboru podnikania previest' do súhrnného odhadu budúceho vývoja konkurenčného pol'a podniku (krok 7). Až potom má zmysel použit' SWOT analýzu, ale dôsledne v kontexte so silnými a slabými stránkami hlavných konkurentov (krok 8). V d’alšom kroku rozvahy do popredia vystúpia kontúry zotrvačného vývoja , ktorý by nastal, pokial' by podnik bez zmien pokračoval v realizácii svojej súčasnej stratégie (krok 9). Ak by tento vývoj viedol k ohrozeniu podniku , či nedostatočnému využitiu jeho príležitostí, je nutné kreatívne zapracovat' inovovanú aktívnu stratégiu podniku (krok 10). Tú je potrebné konfrontovat' s pravdepodobnými protiakciami konkurentov (krok 11). A práve protiakcie konkurentov a d'al'ších aktérov v obore voči novej konkurenčnej stratégii vlastného podniku môžu viest' k ohrozeniu nového zámeru. Preto je nutné ho bud' posilnit', urýchlit' a viac chránit' pred predčasným prezradením alebo v prípade nedostatku zdrojov zvolit' niektorú zo známych ústupových podnikatel'ských taktík.

\footnotetext{
* Ing. Jana Tulisová, Žilinská univerzita v Žiline Univerzitná 8215/1

01026 Žilina.

tel.: +421-41-513 3144

e-mail: jana.tulisova@fpedas.uniza.sk
} 


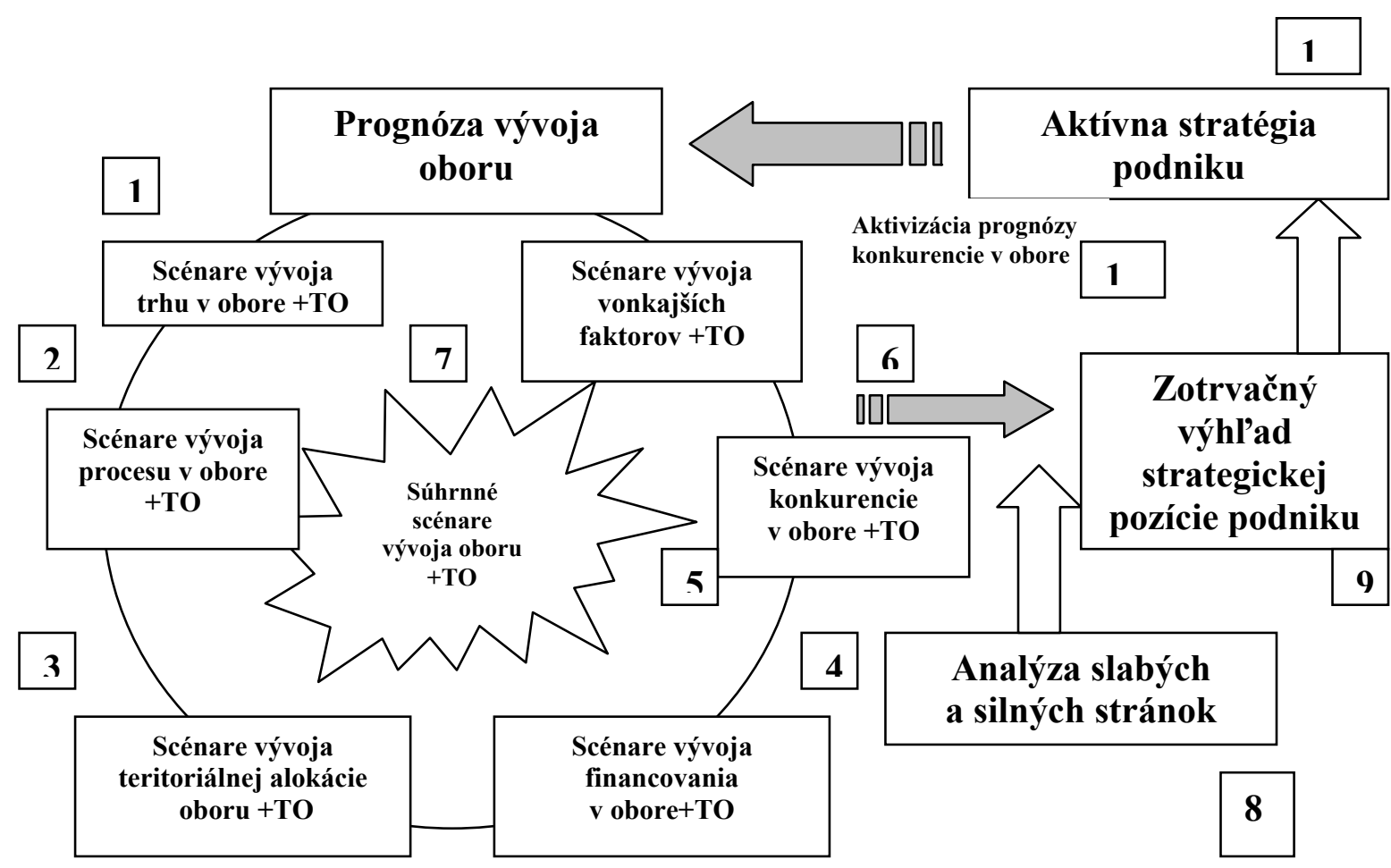

\section{Obrázok 1 Dynamická strategická rozvaha (Zdroj : FISER, I. : Dynamická strategická rozvaha, Moderní řízení, 4/2007 in press )}

Výhodou DSR je využitie poznatkov z východiskovej analýzy a prognózy vývoja oboru, pretože tie, významne ul'ahčujú a skvalitňujú odhadovanie nebezpečných konkurenčných protiakcií voči inovovanej stratégií podniku. Základom tejto novej metódy je špirálový proces tvorivého myslenia, premýšlania a kombinovania, ktoré využíva praktickú predstavivost' a jej postupnú kultiváciu pomocou postupného doplňovania nových poznatkov a informácií. $Z$ toho dôvodu je v názvu metódy použité slovné spojenie „dynamická rozvaha“, ktorá vhodne charakterizuje postup nášho myslenia. Budúcnost' nie je možné mechanicky vykalkulovat', ale je nevyhnutné ju odhadovat' aj za zložitej neurčitosti. DSR nevedie k nebezpečnému redukovaniu situácie rozhodovatel'a len na tie prvky, ktoré je možné merat' a ich trendy vypočítat'. Naopak, podnecuje plné využitie všetkých predností nášho myslenia vrátane intuície a fantázie. No neponecháva ich napospas nekontrolovatel'ných spontánnych duševných pochodov, ale poskytuje im systémovú oporu podobne ako je tomu u základných metód rozhodovania. DSR tým, že vzájomne prepojuje jednotlivé, často i bežné prvky do prirodzeného logického sledu, umožňuje i menej skúsenému strategickému rozhodovatel'ovi úspešne zvládnut' postupné odvodzovanie a kombinovanie strategických úvah. Výhodou je možnost' vel'mi rýchlo zrealizovat' prvú strategickú rozvahu a následne ju v reálnom čase a za rozumných nákladov v d'alších krokoch spresňovat' alebo zásadne menit' na základe nových informácií a nových skúseností s aplikáciou DSR. Strategické myslenie sa tak rýchlo kultivuje a stáva sa pružnejším, dynamickejším a do značnej miery i slobodnejším. DSR pomáha podstatne kultivovat' účast' tímov na strategickom riadení a racionálnejšie využívat' doposial' bežne používané metódy, podporujúce strategické myslenie a rozhodovanie. [1] 


\section{Stručný popis jednotlivých krokov}

Nasledujúci obrázok 2 popisuje kroky metódy DSR. Sekvencia a obsah jednotlivých krokov nepredstavujú dogmu a je nutné ich prispôsobit' zvláštnostiam a možnostiam podnikov rôznych typov.

\section{Scénare vývoja thru v sektore}

- Očakávaný vývoj dopytu v čase (hlavné trendy, milníky, varianty...).

- Vývoj ponuky v čase (nové výrobky, služby, cena...).

- Vývoj možných obmedzujúcich a podporujúcich faktorov trhu.

- Vývoj kúpnej sily a požiadavok zákazníkov.

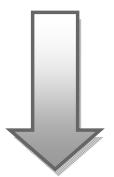

\section{Scénare vývoja procesov $v$ sektore}

- Trendy v oblasti vývoja, výskumu .

- Trendy v oblasti strategického riadenia.

- Vývoj hlavných operácií.

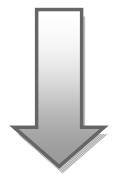

\section{Scénare vývoja teritoriálnej alokácie}

- Vývoj rozmiestnenia klúčových a teritoriáknych zákazníkov, riadicich centier, výzkumu a vývoja strategických služieb a d'alších významných operácií.

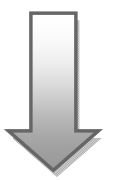

\section{Scénare financovania $\mathbf{v}$ sektore}

- Vývoj foriem investovania v sektore a jeho rentability.

- Vývoj prítažlivosti sektora pre investorov vporovnaní s konkurenčnými sektormi.

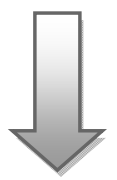

\section{Scénare vývoja konkurencie v sektore}

- Vývoj počtu hlavných konkurentov v sektore a ich vel'kosti.

- Vývoj konkurenčnej schopnosti hlavných i menších konkurentov a ich konkurenčných praktík (cenová vojna, znižovanie nákladov, nové produkty, nadštandartné služby, agresívny marketing...) 




\section{Scénare vývoja vonkajších faktorov}

- Stručný scénar vývoja kritických faktorov v rámci širšieho okolia (politického, ekonomického, sociálneho, ekologického.....)

\section{Súhrnný scenár vývoja sektora}

- Stručný scénar zahŕňa hlavné udalosti, ich očakávané zmeny a rôzne možné varianty vývoja sektora ako celku.

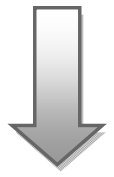

\section{Analýza slabých a silných stránok podniku}

- Stručný scénar vývoja kritických slabých a silných stránok podniku odvodených zo súhrnného scénara vývoja sektora.

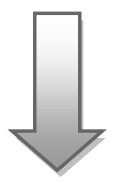

\section{Výhl'ad konkurenčnej pozície podniku v sektore}

- Odhad konkurenčnej pozície podniku v sektore a jeho vývoja za predpokladu, že podnik bude pokračovat' $v$ doterajšej stratégii .

\section{Aktívna stratégia podniku}

- Návrh cielov, postupov a akcií, ktoré budú obsahom inovácií doterajšej stratégie, alebo budú základom novej stratégie. 


\section{Aktivizácia prognózy vývoja sektora}

- Odhady dôsledkov realizácie novej aktívnej stratégie na vývoj klúčových faktorov v sektore, hlavne na konkurenčné protiakcie nebezpečných súperov na trhu.

- Na tento krok nadnäzuje preverenie novej aktívnej stratégie podniku a jej zmeny.

\section{Obrázok 2 Kroky metódy DSR (Zdroj : FISER, I. : Dynamická strategická rozvaha, Moderní řízení, 4/2007 in press - upravené podl’a autorky )}

\section{Záver}

DSR slúži k rýchlej, ale komplexnej orientácii v celkovom vývoji situácie v obore, v ktorom podnik pôsobí. Vymedzenie oboru nesmie byt' príliš široké, pretože inak hrozí roztrieštenie DSR do nerealizovatel'nej podoby. Doporučuje sa stručná formulácia záverov z jednotlivých krokov, pretože len stručnost' záznamu umožní prehl'adnost' a zvládnutel'nost' súvislostí, úvah o aktuálnej pozícii daného podniku v konkurenčnom poli sektora. Je to práve prehl'adný obraz súvislostí, ktorý umožňuje vidiet' pozíciu podniku v novom svetle. Je potrebné pracovat' s odhadmi a hypotézami, ktoré budú overené v d'al'ších kolách aplikácie metódy, kedy bude možné kvalifikovanejšie rozhodnút', na čo sa pri získavaní d'al'ších často nákladných informácií zamerat' a ako podstatným spôsobom skvalitnit' vlastné konkurenčné spravodajstvo podniku. V prvom kole aplikácie metódy je vel'mi nápomocné zjednodušovanie, inak hrozí „utopenie $\mathrm{sa}^{\text {“ }} \mathrm{v}$ množstve detailov a nepodstatných faktorov. Tiež by hrozilo možné pret’aženie a znechutenie členov tímu.

Chyby a omyly pri aplikácii DSR je možné pomerne rýchlo odstraňovat', pretože táto metóda $v$ sebe zahŕňa vel'ký rozvojový potenciál spol'ahlivo vedúci $k$ modernému dynamicky sa učiacemu podniku. [1], [3]

\section{Literatúra}

[1] FISER, I. : Dynamická strategická rozvaha, Moderní ř́zení, Praha.4/2007 in press, str. 31

[2] HAVLÍČEK, K..: Strategie podniku, Moderní řízení, Praha. 2/2011 in press

[3] LUECKE, R.: Strategy, Create and Implement the Best Strategy for your Business, Harvard Business School Publishing Corporation, Massachusetts, 2005. ISBN 978-1-59139-632-1

\section{Grantová podpora}

Príspevok je publikovaný v rámci riešenia projektu VEGA 1/0757/09 Metódy a techniky strategického manažmentu ako nástroje zvyšovania efektívnosti podniku a projektu VEGA 1/0760/10 Využitie strategického manažmentu pre podporu rozvoja regiónov. 